\title{
Effect of the Viral Proteins on the Fluidity of the Membrane Lipids in Sindbis Virus
}

\author{
Bartholomew M. Sheton† and Betty Jean Gaffeney $\ddagger$ \\ $\dagger$ Department of Biology, Massachusetts Institute of Technology \\ Cambridge, Mass. 02139, U.S.A. \\ $\ddagger$ Department of Chemistry, The Johns Hopkins University \\ Baltimore, 21218, U.S.A.
}

(Received 24 July 1974)

\begin{abstract}
The fluidity of the lipids in the membrane of Sindbis virus was studied by electron paramagnetic resonance spectroscopy. The lipids in the viral membrane are noticeably less fluid than the lipids in the membrane of the cells in which the virus was grown. This difference in fluidity is not due simply to differences in lipid composition but instead appears to be the result of the interaction of the viral proteins with the membrene lipids. This conclusion seems clear because (i) the viral lipids are more fluid after extraction with chloroform/metha. nol than in the lipid bilayer of the virion and because (ii) the viral membrane is made more fluid by proteolytic digestion of the viral glycoproteins.

The possible role of this viral protein-mediated alteration of the physical state of membrane lipids in the maturation of Sindbis virions is discussed.
\end{abstract}

\section{Introduction}

Sindbis virus is a small, spherical, lipid enveloped virus. The Sindbis virion consists simply of a non-segmented single-stranded ribonucleic acid genome, three structural proteins, two of which are glycosylated, and lipid. The lipids in the Sindbis membrane are arranged in a bilayer sphere which, from the electron density profile, has a radius to the center of the bilayer of $232 \AA$ (Harrison et al., 1971). The lipid bilayer is bordered very closely by the two viral glycoproteins on the outside and by the nucleocapsid of the virus on the inner side. The nature and the extent of the interaction of the viral proteins with the lipids in the membrane is not known in detail, though it has been estimated from the apparent electron density that only a small portion of the bilayer can be occupied by protein (Harrison et al., 1971). The viral genome directs the synthesis of the three viral proteins (Strauss et al., 1969). In contrast, the lipids in the viral membrane are cellular in origin, are incorporated into maturing virus somewhat non-specifically and, in large part, are synthesized by the cell prior to infection (Pfefferkorn \& Hunter, 1963; Quigley et al., 1971; Hirschberg \& Robbins, 1974). The host cell plasma membrane appears to be the source of the viral lipids since the virus core can be seen with electron microscopy to acquire a membrane only at the cell surface (Acheson \& Tamm, 1967; Brown et al., 1972) and because the phospholipid composition of the virus more closely resembles that of the plasma membrane than that of the whole cell (Quigley et al., 1971; Hirschberg \& Robbins, 1974). During the final stages in virus assembly, the preassembled viral ribonucleoprotein core becomes 
enveloped by a portion of the host cell plasma membrane which has been modified so as to contain only viral proteins. During this process the viral and cellular membranes are continuous structures.

This work was undertaken to determine whether there exists a difference between the physical properties of the lipids in the Sindbis membrane and lipids in the host cell membrane and to determine how strongly the viral proteins affect the physical properties of the viral membrane lipids. To this end, several spin-labeled lipids, I, II, III $(m, n)$ and IV, have been incorporated into viral and cellular membranes and their paramagnetic resonance spectra have been examined. The spectra of spin labels I, II, and III $(m, n)$ are sensitive to the flexibility of the acyl chains of the membrane lipids (Gaffney, 1974). The spin labels were used to compare lipid fluidity in the viral membrane with that in (i) cellular membranes; (ii) viral membranes modified by proteolysis, and (iii) the extracted viral lipids.

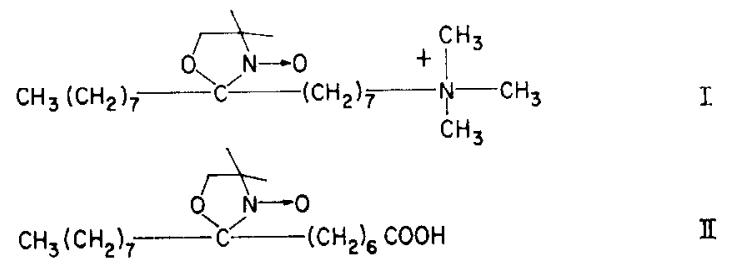

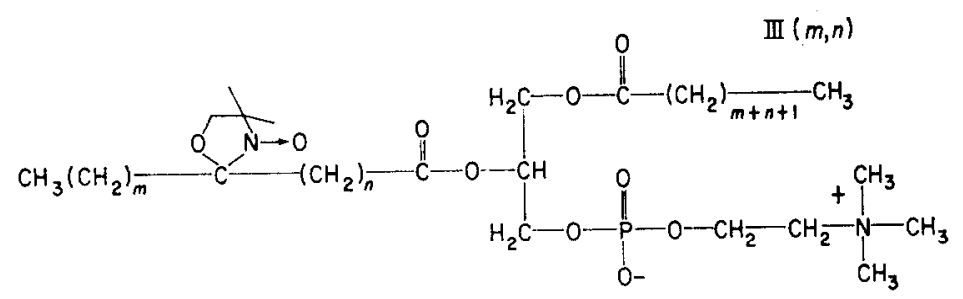

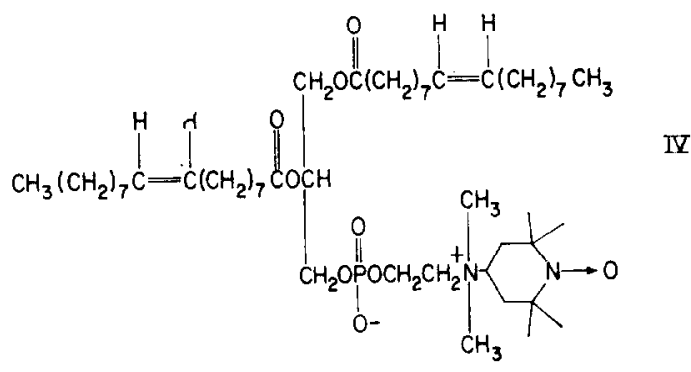

\section{Materials and Methods}

\section{(a) Buffers}

Tris/NaCl/EDTA is $0.05 \mathrm{~m}-$ Tris $\cdot \mathrm{HCl}, 0.15 \mathrm{M}-\mathrm{NaCl}$ and $0.001 \mathrm{~m}-\mathrm{EDTA}, \mathrm{pH} 7 \cdot 4$.

Tris $/ \mathrm{NaCl} / \mathrm{Ca}$ is $0.075 \mathrm{M}$-Tris $\cdot \mathrm{HCl}, 0.075 \mathrm{M}-\mathrm{NaCl}$ and $0.01 \mathrm{M}-\mathrm{CaCl}_{2}, \mathrm{pH} 8 \cdot 0$.

(b) Growth of the cells and virus

All virus was grown in chick embryo fibroblasts. Primary cultures were prepared essentially as described by Rein \& Rubin (1968). Secondary cultures were prepared by trypsinization and reseeding of the cells in large glass roller bottles $\left(1200 \mathrm{~cm}^{2}\right.$ growth area). The cells were grown to confluence, approximately 1 to $2 \times 10^{8}$ cells per roller bottle, at $37^{\circ} \mathrm{C}$ in Eagle's medium (Eagle, 1959) supplemented with $5 \%$ calf serum and $2 \%$ heat-activated chicken serum. Infection was at a low multiplicity of virus, approxi- 
mately 0.05 to 0.1 plaque-forming unit per cell, in Eagle's medium supplemented with $2 \%$ tryptose phosphate broth and $1 \%$ calf serum. The infection was allowed to proceed for 24 to $30 \mathrm{~h}$ at $30^{\circ} \mathrm{C}$. The virus was purified by precipitation with polyethylene glyen and velocity sucrose gradient centrifugation as has been described in detail (Sefton \& Keegstra, 1974). Cells to be used for spin label experiments and membrane preparation were grown as described above except that they were grown on plastic Petri dishes (Falcon).

\section{(c) Incorporation of spin labeled lipids}

The synthesis of fatty acid spin label II has been described previously (Hubbell \& McConnell, 1971). Label I was prepared by reduction of II to the corresponding alcohol, conversion of the alcohol to a bromide, and reaction of the bromide with trimethylamine. Details of the synthesis of I will be published elsewhere (B. J. Gaffney, unpublished data). Labels III $(m, n)$ were prepared by acylation of lysolecithin as described by Hubbell \& McConnell (1971). For labels III $(10,3),(7,6)$ and $(5,10)$, lysolecithin was prepared from egg lecithin. For label III $(1,14)$, dipalmitoyl lecithin was used. Label IV was a gift of Mark McNamee and its preparation has been described (McNamee \& McConnell, 1973).

The method by which the spin labeled lipids were incorporated into the samples varied with the type of label used. Label I was incorporated into whole virus by the addition of a small volume of an aqueous solution of the label to a pellet of virus which had been precipitated by dilution to low ionic strength (Sefton et al., 1973). Label I was added to cells in a generally similar manner. The cells, attached to a plastic Petri dish, were washed with calcium/magnesium-free phosphate-buffered saline (Dulbecco \& Vogt, 1954) and then concentrated at one side of the dish by scraping with a rubber policeman. The label, in an aqueous solution, was added diroctly to the cells. For addition of label II to cells, an ethanol solution of the label was evaporated on a bare portion of the dish after the cells had been scraped away. After evaporation of ethanol, the cells were placed in contact with the residue of spin label and rapidly took up the label. Labels I and II were incorporated similarly into protease-digested virus subsequent to the proteolysis. Labels II and III $(m, n)$ were added to solutions of extracted lipids dissolved in chloroform/ methanol $(2: 1 \mathrm{v} / \mathrm{v})$, and the resulting mixture was evaporated to dryness under a stream of nitrogen and resuspended in Tris/NaCl/EDTA.

The phospholipid spin labels III $(m, n)$ were incorporated into virus by fusion of soni. cated vesicles of spin label lipids with the virus. Vesicles were prepared by sonication of an ice-cold suspension of labels III $(m, n)$ or label IV in several $\mathrm{ml}$ of Tris/NaCl/EDTA buffer. Sonication was for 45 min with a Branson model 1850 cell disrupter equipped with a $1 \mathrm{~cm}$ titanium probe and supplying $60 \mathrm{~W}$ of power. Titanium particles were sometimes removed from the resulting gray suspension by centrifugation. The suspension of sonicated vesicles was then added to a pellet of virus, prepared by dilution and centrifugation, and the resulting solution was incubated at $37^{\circ} \mathrm{C}$ for 15 to $30 \mathrm{~min}$. The virus was recovered from this solution by the addition of 10 vol. of ice-cold water and centrifugation at $18,000 \mathrm{~g}$ for $10 \mathrm{~min}$. The resulting pellet was dissolved in 1 to $2 \mathrm{ml}$ of $\mathrm{Tris} / \mathrm{NaCl} / \mathrm{Ca}$, and incubated at $37^{\circ} \mathrm{C}$ for $60 \mathrm{~min}$ to remove unfused label. The virus was recovered by dilution and contrifugation as just described.

The preparation of vesicles of III $(1,14)$ differed slightly from the above procedure. The labeled phospholipid was prepared from dipalmitoyl lecithin and thus it contained palmitic acid chains in both the $\beta$ - and $\gamma$-positions. As a result of this homogeneous fatty acid composition, this label has a phase transition at about $24^{\circ} \mathrm{C}$. Therefore, during preparation of III $(1,14)$ vesicles, the lipid suspension was cooled in a water bath to only $25^{\circ} \mathrm{C}$. Subsequent operations were as described for the phospholipid labels except that all were carried out at $25^{\circ} \mathrm{C}$.

\section{(d) Proteolysis}

Prior to Pronase digestion, the Pronase $(10 \mathrm{mg} / \mathrm{ml}$, Calbiochem A grade), dissolved in Tris/ $\mathrm{NaCl} / \mathrm{Ca}$ buffer, was predigested for $2 \mathrm{~h}$ at $37^{\circ} \mathrm{C}$ to destroy non-proteolytic activity. The virus pellet (usually $1.5 \mathrm{mg}$ of viral protein) was dissolved in the $1.0 \mathrm{ml}$ of Tris/ $\mathrm{NaCl} / \mathrm{Ca}$ buffer, Fronase was added to a concentration of $2 \mathrm{mg} / \mathrm{ml}$ and the mixture was 
incubated at $37^{\circ} \mathrm{C}$ for $60 \mathrm{~min}$. The reaction was terminated by the addition of 10 vol. of ice-cold water. The digested virus was recovered by centrifugation at $18,000 \mathrm{~g}$ for 20 to 30 min. Digestion with mixed trypsin and chymotrypsin (Worthington) was performed with $2 \mathrm{mg}$ of each enzyme in $1.0 \mathrm{ml}$ of Tris/NaCl$/ \mathrm{Ca}$ buffer. Thermolysin (Calbiochem) digestion was with a nominal $1 \mathrm{mg} / \mathrm{ml}$ solution in $1.0 \mathrm{ml}$ of $\mathrm{pH} 7 \cdot 4$ buffer $(0 \cdot 1 \mathrm{M}-\mathrm{NaCl}$, $0.05 \mathrm{M}$-Tris $\cdot \mathrm{HCl}, 0.005 \mathrm{M}-\mathrm{CaCl}_{2}$ ) and was carried out for $90 \mathrm{~min}$.

\section{(e) Membrane preparation}

Cell plasma membranes were prepared by the method described by Perdue et al. (1971). Briefly, the cells were scraped from the Petri dish with a rubber policeman and suspended in $0.16 \mathrm{~m}-\mathrm{NaCl}$. The cells were disrupted by use of a Potter-Elvehjem homogenizer with a tight-fitting pestle $\left(0.002\right.$ in) for $15 \mathrm{~min}$ at 2 to $4^{\circ} \mathrm{C}$. Particulate material was collected by centrifugation at $150,000 \mathrm{~g}$ for $90 \mathrm{~min}$. The pellet was resuspended in $56 \%$ $(\mathrm{w} / \mathrm{w})$ sucrose in water and a $23 \%$ to $53 \%(\mathrm{w} / \mathrm{w})$ sucrose in water gradient was formed over this solution and centrifuged at $80,000 \mathrm{~g}$ for $14 \mathrm{~h}$. The material floating at the top of the gradient was removed, diluted with water and pelleted by centrifugation at $150,000 \mathrm{~g}$ for $1 \mathrm{~h}$. The resulting pellet was again dissolved in water and pelleted by centrifugation.

\section{(f) Lipid extraction}

When lipids were to be extracted from a preparation of cellular plasma membranes, the membranes were suspended in $1.0 \mathrm{ml}$ of $50 \%$ methanol in water and were dryed under a stream of nitrogen. Viral pellets for lipid extraction were dryed under nitrogen after the addition of $0.5 \mathrm{ml}$ of methanol. Subsequent steps were the same for both preparations. The dry samples were extracted twice with 1.5 to $\cdot 2 \cdot 0 \mathrm{ml}$ of chloroform/methanol $(2: 1, \mathrm{v} / \mathrm{v})$ and once with chloroform/methanol $(1: 2, \mathrm{v} / \mathrm{v})$ by vigorous mixing. The resulting solution was passed through glass wool to remove insoluble protein and dried under nitrogen. The lipids were then dissolved in $5 \mathrm{ml}$ of chloroform/methanol $/ 0.01 \mathrm{~N}-$ $\mathrm{HCl}(8: 4: 3)$, mixed vigorously and centrifuged to separate the 2 phases. The aqueous phase was discarded and solid sodium bicarbonate was added to neutralize any residual $\mathrm{HCl}$. The suspension was mixed and filtered through glass wool. The appropriate spin labeled lipid was then added and the lipids dried under nitrogen or in vacuo. The lipids were then resuspended in $25 \mu \mathrm{l}$ of Tris/NaCl/EDTA buffer by use of a Vortex mixer.

\section{(g) Radioactive labeling of the virus}

Virus labeled with a mixture of radioactive amino acids was produced by one step of growth on chick embryo cells. Infection was at a high multiplicity of virus, greater than 100 plaque-forming units per cell, and was allowed to proceed for 12 to $14 \mathrm{~h}$ at $38 \cdot 5^{\circ} \mathrm{C}$. The growth medium, Eagle's medium supplemented with $2 \%$ tryptose phosphate broth and $1 \%$ calf serum, contained 0.1 the normal concentration of amino acids, except glutamine, and 2 to $5 \mu \mathrm{Ci}$ of a mixture of radioactive amino acids (New England Nuclear). Purification was as previously described (Sefton \& Keegstra, 1974).

When virus was to be labeled with $\left[{ }^{14} \mathrm{C}\right]$ palmitate, the chick cells to be used for virus growth were incubated for $24 \mathrm{~h}$ prior to infection with medium containing $\left[{ }^{14} \mathrm{C}\right]$ palmitate $(0.25$ to $0.50 \mu \mathrm{Ci} / \mathrm{ml}$, New England Nuclear). The palmitate label was adsorbed to fetal calf serum by sonication prior to addition to the medium (Robbins \& Macpherson, 1971). Infection, growth and purification were as just described except that the normal concentration of amino acids was present in the growth medium.

\section{(h) Proteolysis and electrophoresis of radioactive virus}

Virus, labeled with $\left[{ }^{14} \mathrm{C}\right]$ palmitate, was mixed with virus labeled with a mixture of ${ }^{3} \mathrm{H}$-labeled amino acids and $250 \mu \mathrm{g}$ of unlabeled virus. This mixture was divided and both parts were precipitated by dilution and collected by centrifugation. One was saved as control. The other was dissolved in $0.4 \mathrm{ml}$ of Tris $/ \mathrm{NaCl} / \mathrm{Ca}$ buffer and $500 \mu \mathrm{g}(0.1 \mathrm{ml})$ of Pronase was added. The mixture was incubated for $60 \mathrm{~min}$ at $37^{\circ} \mathrm{C}$ and then layered over a $20 \%$ to $50 \%(\mathrm{w} / \mathrm{w})$ sucrose in Tris/NaCl/EDTA gradient containing $0.9 \%$ calf serum. The gradient was centrifuged for $10 \mathrm{~h}$ at $80,000 \mathrm{~g}$, fractionated and those fractions containing the virus pooled. These fractions $(1.8 \mathrm{ml})$ were diluted to $9.5 \mathrm{ml}$ with 
water containing $2 \%$ calf serum and $10 \mathrm{mg}$ ovomucoid and centrifuged at $150,000 \mathrm{~g}$ for $2 \mathrm{~h}$. The pellet was dissolved in $0.4 \mathrm{ml}$ of $2 \%$ sodium dodecyl sulfate, 5 mm-sodium phosphate buffer ( $\mathrm{pH} 7 \cdot 0), 15 \%(\mathrm{v} / \mathrm{v})$ glycerol and 2 mM-phenyl methane sulfonyl fluoride by heating to $100^{\circ} \mathrm{C}$ for several minutes.

Proteolysis of virus labeled with ${ }^{14} \mathrm{C}$-labeled amino acids (Fig. 4) was essentially as has just been described. The final pellet was dissolved in $0.4 \mathrm{ml}$ of the above sodium dodecyl sulfate-containing solution in which the ${ }^{3} \mathrm{H}$-labeled amino acid marker virus had already been dissolved. Sodium dodecyl sulfate-polyacrylamide gel electrophoresis was essentially as described by Laemmli (1970) with previously described modifications (Sefton \& Burge, 1973 ) in gels containing $\mathbf{7 . 5} \%$ acrylamide.

\section{(i) Spectroscopy}

Paramagnetic resonance signals were recorded on a Varian E9 spectrometer equipped with a variable temperature controller. Samples were placed in $50 \cdot \mu$ l disposable glass capillaries (Corning) which were sealed at one end. Modulation amplitudes were one gauss or less and the microwave power was kept at or below $10 \mathrm{~mW}$ to avoid sample heating and signal saturation. The temperature was monitored using a copper constantin thermocouple placed just above the resonance area of the cavity. Comparisons of several samples using a single label were performed without variation of the settings on the temperature controller or the position of the sample holder.

\section{(j) Calculation of order parameters}

Order parameters $(S)$ were calculated according to the following equation (Gaffney, 1974):

$$
S=\frac{T_{\|}^{\prime}-\left(T_{\perp}^{\prime}+C\right)}{T_{\|}^{\prime}+2\left(T_{\perp}^{\prime}+C\right)} \times 1 \cdot 723 .
$$

This equation is derived from that of Hubbell \& McConnell (1971) by including estimatod single crystal parameters for fatty acid spin labels and a term $C$ which corrects for the deviation of the observed value of $T_{\perp}^{\prime}$ from the actual value

$$
C=1 \cdot 4-0.053\left(T_{\|}^{\prime}-T_{\perp}{ }^{\prime}\right) \text { gauss. }
$$

\section{Results}

\section{(a) Comparison of the Sindbis virus membrane and the chick cell membrane}

The behavior of spin label $I$ in Sindbis virus and in whole chick cells was compared. Since this experiment was designed to determine whether the viral membrane was different from the membrane of the cell in which the virus was grown, cells grown in the same manner as those used during growth of the purified virus were used. A potentially important factor was that the virus used in this and in the subsequent experiments was grown in chick cells incubated during virus growth at $30^{\circ} \mathrm{C}$. Actually, the growth temperature of either the virus or the cells had little effect on the inherent physical properties of either of the membranes (see below). Spin label I, dissolved in water, was added directly to a pellet of virus or to cells concentrated by scraping to one side of a Petri dish. The samples were immediately transferred to a capillary tube and the appropriate measurements made. The mobility of the label in the virus was noticeably less than in the cells. The observed order parameter of the label in the two samples, as a function of the temperature at which the measurement was made, is plotted in Figure 1. In this plot, a solid would have an order parameter of one and a fluid, isotropic liquid would have an order parameter of zero. At all temperatures, the label in the virus (Fig. 1, curve A) was more immobilized (had a higher order parameter) than it was in the plasma membrane of the chick cell (Fig. 1, curve D). The 


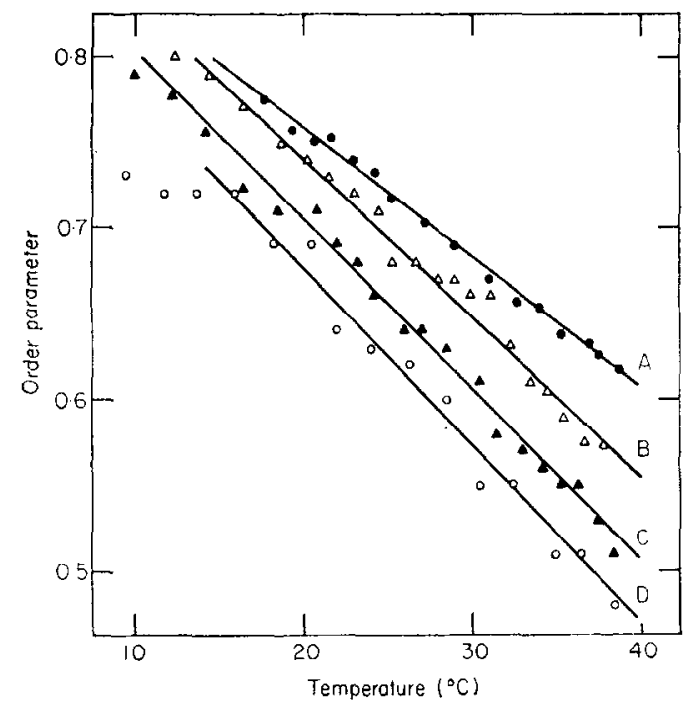

Fia. 1. The temperature dependence of the order parameter for the alkyl trimethylammonium spin label, I, in curve A, intact virus; curve B, Pronase-treated virus; curve C, chloroform/ methanol-extracted viral lipids and curve D, intact chick cells. Order parameters were calculated as described in Materials and Methods.

assumption that label $I$ is localized in the plasma membrane of whole cells is based on the observation that during measurements in whole cells the paramagnetism of $I$ is destroyed with a half-time of approximately 30 minutes. It is assumed that the oss of label signal is due to chemical reduction when the label is internalized by the cell.

It was possible that the relative rigidity of the viral membrane was a consequence simply of lipid composition. Therefore, the viral lipids were extracted with chloroform/methanol, mixed with spin label I, dried under a stream of nitrogen and rehydrated in buffer. The temperature dependence of the fluidity of the viral lipids, in the absence of the viral proteins, is shown in Figure 1, curve C. The viral lipids were much more fluid (had a lower order parameter) after extraction than they were in the intact virion.

It thus appeared that the rigidity of the viral membrane relative to either the chick cell plasma membrane or the extracted viral lipids must be due, in large part, to the viral proteins. Therefore, the virus was digested with Pronase for 60 minutes in order to remove as much of the two external viral glycoproteins as possible. This treatment did not destroy the structural integrity of the virion (Harrison \& Sefton, unpublished data), as is also the case for both bromelain digestion of Sindbis virus (Compans, 1971), and thermolysin digestion of a virus very closely related to Sindbis, Semliki Forest virus (Gahmberg et al., 1972). The order parameter of label I in Pronase-digested Sindbis virus was less than that in the intact virus, but not as low as in the extracted viral lipids (Fig. 1, curve B). This result suggests that the viral glycoproteins participate in the immobilization of the viral lipids and that Pronase digestion of the virus is not able to remove all restraints on the movement of the viral lipids.

The ability to make the viral membrane more fluid is not unique to the mixture of proteases sold commercially as Pronase. Both thermolysin and a mixture of trypsin 
TABLE 1

Effect of proteolysis on the fluidity of the Sindbis virus membrane

\begin{tabular}{|c|c|c|c|c|c|}
\hline \multirow{2}{*}{ Label } & \multirow{2}{*}{$\begin{array}{l}\text { Tomperature } \\
\text { of measurement } \\
\qquad\left({ }^{\circ} \mathrm{C}\right)\end{array}$} & \multirow{2}{*}{$\begin{array}{l}\text { Intact } \\
\text { virus }\end{array}$} & \multicolumn{3}{|c|}{$\begin{array}{c}\text { Order parameter } \\
\text { Protease-treated virus }\end{array}$} \\
\hline & & & $\begin{array}{l}\text { Trypsin and } \\
\text { chymotrypsin }\end{array}$ & Pronaso & Thermolysin \\
\hline $\begin{array}{l}\text { I }(7,7) \\
\text { Alkyltrimethyl }\end{array}$ & $37 \cdot 7$ & $0 \cdot 64$ & 0.59 & $0 \cdot 60$ & \\
\hline ammonium label & 25 & $0 \cdot 73$ & $0 \cdot 70$ & & 0.70 \\
\hline $\begin{array}{l}\text { II }(7,6) \\
\text { Fatty acid } \\
\text { label }\end{array}$ & $37 \cdot 7$ & $0 \cdot 64$ & $0 \cdot 60$ & & \\
\hline
\end{tabular}

Order parameters were caloulated as described in Materials and Methods. The values prosented are those of representative experiments.

and chymotrypsin made the viral membrane more fluid (Table 1). Further, a decrease in order parameter as a result of proteolysis was detected with a variety of spin labeled lipids. Positively charged (Fig. 1 and Table 1), negatively charged (Table 1) and uncharged labels (see below) all showed the viral membrane to be more fluid after proteolysis. This strengthens the idea that proteolytic destruction of the viral glycoproteins makes the viral membrane more fluid.

\section{(b) Studies with spin labeled phospholipids}

The results shown in Figure 1 were obtained with the spin label moiety at a single position on the hydrocarbon chain of the label. In order to further compare intact virus, Pronase-digested virus and extracted viral lipids, phospholipid labels III $(m, n)$ were employed. Use of phospholipid labels is desirable because phospholipid is the principal lipid in both the viral and cellular membranes and because these labels are certainly localized exclusively in the membranes.

Four phospholipid labels, III $(m, n)$, with the paramagnetic nitroxide ring in various positions on the $\beta$-fatty acyl chain were used. These labels provide a measure of the relative flexibility of hydrocarbon chains at different levels in the bilayer. The phospholipid spin labels were introduced into the virus by fusion of small, sonicated vesicles of spin labeled lipid with the virus. A ratio of lipids in the virus to added spin labeled lipid of 9:1 was used except for III $(1,14)$ where the ratio was $19: 1$. Under these conditions, enough spin labeled lipid was incorporated into viral membranes to permit spectral measurements. The incorporated lipid represented only a fraction of both the total spin label added to the fusion mixture and of the total viral lipid. After excess spin labeled vesicles were removed by washing, sharp signals typical of dilute label concentrations were observed.

The mechanism of fusion of lipid vesicles with the virus is unknown. However, because virus and lipid vesicle radii are of comparable magnitudes and because there 
is evidence of a low concentration of spin labeled lipid in the virus after fusion, it is unlikely that complete intermixing of one virus and one lipid vesicle predominates, although a background signal due to a low level of this type of fusion cannot be ruled out. A preliminary investigation of the distribution of label between the inner and the outer sides of the virus membrane was performed. For these studies, a head-group labeled phosphatidyl choline, IV, was allowed to fuse with the virus. Ascorbate reduction of the nitroxide portion of this molecule (Kornberg \& McConnell, 1971) was used as a means of quantitating label on the inside and outside of the bilaycr. $\Delta t$ least

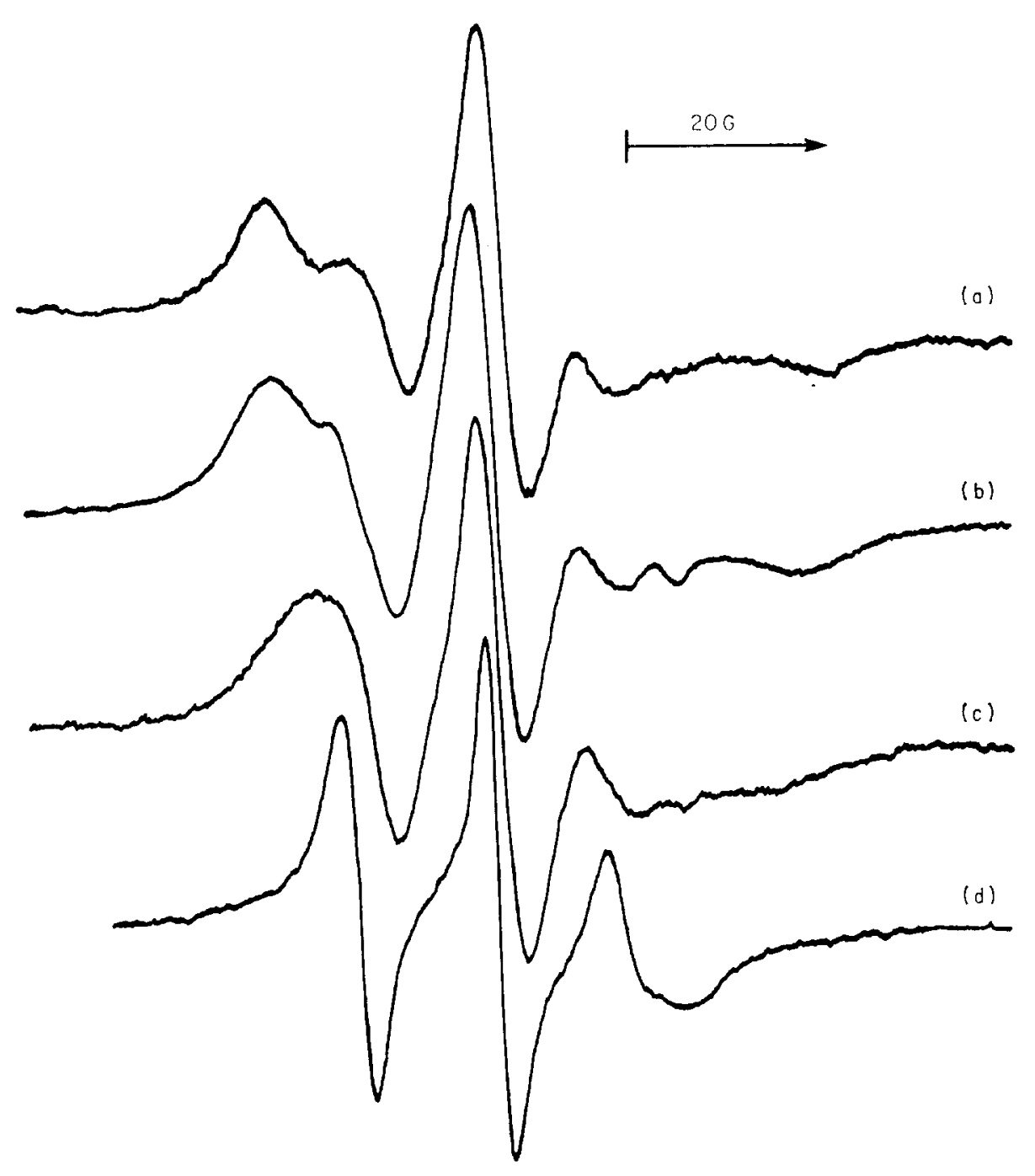

Fig. 2. The paramagnetic resonance spectra of phospholipid spin labels III $(m, n)$ incorporated into the membrane of Sindbis virus. The spectra are of labels (a) III $(10,3)$; (b) III $(7,6)$; (c) III $(5,10)$, and (d) III $(1,14)$. Spectra were recorded at $37^{\circ} \mathrm{C}$. 
$\mathbf{2 5} \%$ of the fused, spin labeled lipid was not reduced by the ascorbate and thus is presumed to be on the inside half of the viral membrane. Therefore, the results with the phospholipid labels must represent the combined physical properties of both sides of the membrane.

The paramagnetic resonance spectra of labels III $(m, n)$ in the intact virus are shown in Figure 2. Figure 3 presents the order parameters calculated from the paramagnetic resonance spectra of Figure 2 as well as similar data obtained with Pronase-treated virus and aqueous dispersions of extracted viral lipids. Figure 3 is a plot of the measured order parameter of the label as a function of the position of the nitroxide group

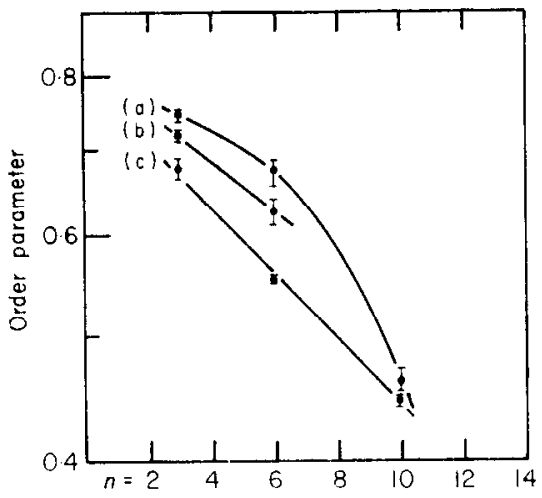

Fre. 3. The order parameters of phospholipid spin labels $I I(m, n)$ at $37 \cdot 7^{\circ} \mathrm{C}$ in (a) intact Sindbis virus; (b) Pronase-treated virus, and (c) chloroform/methanol-extracted viral lipids. Order parameters aire plotted semilogarithmioally as a function of $n$, the number of methylenes between the carboxyl and nitroxide groups on the $\beta$-chains of the incorporated lipids, and were calculated as indicated in Materials and Methods. Three separate messurements are represented for labels III $(10,3)$ and III $(7,6)$. Data for III $(5,10)$ are from two separate measurements. The error bars represent the actual range of values obtained in separate experiments.

on the acyl chain. The decrease in order parameter with increasing $n$ is typical of results obtained with labels III $(m, n)$ in phospholipid bilayers. Differences in fluidity between the intact virus and the extracted lipids were detected with labels at three different levels in the bilayer. Pronase digestion produced a state of intermediate fluidity as measured with two of the phospholipid labels. A quantitative comparison of the results for label I (Fig. 1) and for labels III $(7,6)$ (Fig. 3) cannot be made. Although the spin label moiety of the two labels is at approximately the same position on the hydrocarbon chain, both the depth of the labels in the bilayer and probably their distribution in a heterngeneous lipid population are influenced by the structure and the charge of the polar head group, and thus are not identical. However, qualitatively, the results with the two labels are in agreement.

\section{(c) Effect of proteolysis on the Sindbis proteins}

Interpretation of the effect of Pronase digestion on the viral membrane requires a knowledge of the extent of the removal of viral glycoproteins during the proteolysis. Therefore, virus labeled with a mixture of amino acids was digested as in the spin label experiments, purified by equilibrium sucrose gradient centrifugation, mixed with 
radioactive, undigested virus and subjected to sodium dodecyl sulfate-polyacrylamide gel electrophoresis. No intact glycoproteins were present in the Pronase-treated sample, but material co-migrating with the dye, which was not present in the untreated virus, was seen (Fig. 4). This result suggests that all of the glycoproteins were removed by Pronase. However, it is impossible to conclude from this gel whether the core protein, $\mathrm{C}$, was recovered quantitatively after the proteolysis and

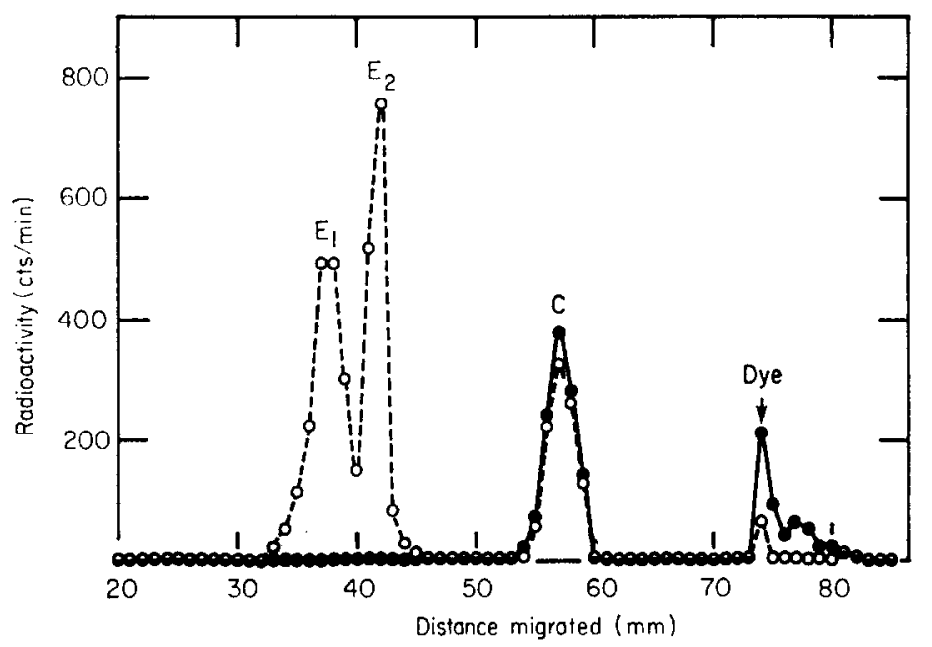

FIG. 4. The polypeptide composition of Pronase-digested Sindbis virus. Sindbis virus was digested with Pronase, purified by equilibrium sucrose-gradient centrifugation, dissolved in a solution of sodium dodecyl sulfate which contained undigested radioactive Sindbis virus and subjected to sodium dodecyl sulfato-polyacrylamide gel electrophoresis, all as described in Materials and Methods.

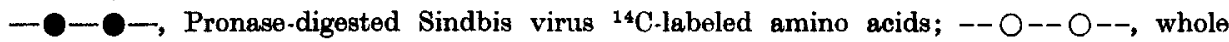
Sindbis virus, ${ }^{\circ} \mathrm{H}$-labeled amino acids.

thus also impossible to determine the origin of the low molecular weight material which migrated with the dye. Therefore, virus labeled with a mixture of amino acids and virus labeled with radioactive palmitate were mixed, digested with Pronase, purified and subjected to electrophoresis. No lipid was lost during the digestion. However, after electrophoresis, the ratio of the amount of amino acid label in the internal viral protein, $\mathrm{C}$, to the amount of palmitate label was reduced by $25 \%$. This result suggests that at some point during the proteolysis, the purification and the disruption with sodium dodecyl sulfate, that approximately $25 \%$ of the protein molecules inside the viral lipid bilayer were digested by Pronase. Where the loss occurred is not clear. This result thus makes it impossible to unambiguously identify the source of the low molecular weight peptides.

\section{(d) Effect of the viral proteins on the center of the lipid bilayer}

In order to investigate how deeply the viral proteins penetrate the lipid bilayer, the behavior of label III $(1,14)$ in whole virus and in extracted viral lipids was compared. The paramagnetic moiety of this label is close to the center of the bilayer and 
thus is not expected to respond to an interaction of viral protein with viral lipid which is only superficial. The paramagnetic resonance spectra of this label in virus and viral lipids were compared at both $37^{\circ} \mathrm{C}$ and $0^{\circ} \mathrm{C}$. Figure 4 shows the spectra of III $(1,14)$ in intact virus and viral lipids at $37^{\circ} \mathrm{C}$. It was not possible to detect differences between the spectra at either temperature. It should be pointed out that changes in the mobility of this label would most likely be manifested as a very small change in line width which might be obscured by noise or a background signal due to a low level of spin label vesicles remaining after washing.

\section{(e) Effects of growth temperature}

As mentioned above, both the virus and the cells used for these studies were grown at $30^{\circ} \mathrm{C}$. Since the measured order parameter of label $\mathrm{I}$ in cells decreases from 0.57 to 0.50 as the temperature is raised from 30 to $37^{\circ} \mathrm{C}$ (Fig. 1), it was possible that the fluidity of virus grown at $37^{\circ} \mathrm{C}$ would be different from that of virus grown at $30^{\circ} \mathrm{C}$. Further it was possible that the cells themselves might alter the lipid composition of their membranes as a function of incubation temperature so that the physical state of membrane lipids would remain unchanged (Sinenski, 1974). To test these possibilities, virus and cells grown at either $30^{\circ} \mathrm{C}$ or $37^{\circ} \mathrm{C}$ were labeled with label I and compared. The growth temperature had little effect on the measured order parameters (Table 2). The difference between the virus samples is close to the limits of experimental error and would require repeated measurements for verification. This difference, if real, indicates that virus grown at a higher temperature may be slightly more fluid.

\section{TABLE 2}

Comparison of (i) cells and virus grown at high and low temperature and (ii) the lipids extracted from cellular and viral membranes

\begin{tabular}{|c|c|c|c|c|}
\hline \multirow{3}{*}{ Label } & \multicolumn{4}{|c|}{ Order par ameter } \\
\hline & \multicolumn{2}{|c|}{$\begin{array}{l}\text { Cells } \\
\text { Incubation temperature } \\
\left({ }^{\circ} \mathrm{C}\right)\end{array}$} & $\begin{array}{l}\text { Cell membrane } \\
\text { lipids }\end{array}$ & $\begin{array}{l}\text { Viral } \\
\text { lipids }\end{array}$ \\
\hline & 30 & 38 & & \\
\hline $\begin{array}{l}\text { I }(7,7) \\
\text { Alkyltrimethyl } \\
\text { ammonium label }\end{array}$ & $0 \cdot 47$ & 0.48 & 0.47 & 0.62 \\
\hline $\begin{array}{l}\text { II }(7,6) \text { Fatty } \\
\text { acid label }\end{array}$ & $\begin{array}{l}0.42 \\
\text { grov }\end{array}$ & $\begin{array}{r}0 \cdot 42 \\
\text { ature }\end{array}$ & & \\
\hline $\begin{array}{l}\text { III }(\mathbf{7}, \mathbf{6}) \\
\text { Phospholipid label }\end{array}$ & $\begin{array}{c}30 \\
0.67\end{array}$ & $\begin{array}{c}38 \\
0 \cdot 66\end{array}$ & $0 \cdot 48$ & 0.56 \\
\hline
\end{tabular}

The order parameters were calculated as deseribed in Materials and Methods. All the spectra were recorded at $37^{\circ} \mathrm{C}$.

\section{(f) Spin label comparison of viral and cellular membrane lipids}

It appears from chemical analysis that the phospholipids and glycolipids of Sindbis virus grown in chick cells resemble those of the surface membrane of chick cells 
(Quigley et al., 1971; Hirschberg \& Robbins, 1974). The chloroform/methanol extractable viral lipids were compared with similarly extracted lipids from a preparation of chick cell surface membranes using both labels I and III $(7,6)$. The cell membranes employed were prepared by the method of Perdue et al. (1971) and are low density, lipid-rich membrane vesicles. The lipids from the membrane preparation were more fluid with both labels than those from the virus (Table 2). This is consistent with chemical analysis which shows that cholesterol represents 44 mole per cent of the viral lipids and 37.5 mole per cent of the lipids of this chick cell plasma membrane preparation (Hirschberg \& Robbins, 1974) and the fact that cholesterol is known to impart considerable rigidity to lipid bilayers at the position of the label used in these experiments (Hubbell \& McConnell, 1971).

\section{Discussion}

The physical properties of the lipids in the membrane of Sindbis virus are different from those of the lipids in the host cell plasma membrane: relatively, the viral lipids are very immobilized. This is striking because the viral membrane is composed of lipids selected almost at random from the cellular plasma membrane (Quigley et al., 1971; Hirschberg \& Robbins, 1974) and because during viral morphogenesis, the viral and cellular membranes are continuous structures. The immobilized state of the viral lipid appears to be due in part to the two viral glycoproteins since proteolytic removal of the glycoproteins makes the viral membrane more fluid. However, the interaction of the glycoproteins with the lipids is probably not solely responsibile for the rigidity of the viral membrane. The chloroform/methanol soluble viral lipids are even more fluid than protease-digested virus.

The contribution of protease-resistant hydrophobic peptide remnants of the viral glycoproteins to the observed partial rigidity of protease-treated virus cannot be accurately estimated. Such fragments have been described in Semliki Forest virus, a virus closely related to Sindbis virus, following digestion with thermolysin (Utermann \& Simons, 1974). However, it can be concluded from the work presented here that proteolysis sufficient to cleave all the viral glycoproteins, and even $25 \%$ of the internal proteins present in a viral preparation, does not remove all the constraints on the movement of the lipids.

The interaction of the viral lipids with the internal ribonucleoprotein core of the virus is probably responsible for much of the rigidity of the membrane which remains after proteolysis. No space between the viral core and the lipid bilayer was detected by X-ray diffraction (Harrison et al., 1971), and the interaction between the core and the membrane is necessarily specific enough that only virally modified patches of cellular membrane are recognized during morphogenesis. Indeed, it is possible that the interaction of the core with virally modified areas of the cell membrane is sufficiently strong that this process alone drives the envelopment and budding of the virus.

The assembly of Sindbis virions at the cell surface necessarily involves formation of virus-specific patches of membrane. These areas differ from the rest of the cellular membrane in two important respects; protein composition and lipid fluidity. The formation of these areas must include (i) aggregation of the viral glycoproteins on the external surface of the host-cell membrane and (ii) trans-membrane recognition between the intracellular viral ribonucleoprotein core and the viral glycoproteins on the cell surface. The sequence of these events is not known. The effect of the viral 
proteins on the fluidity of the lipid bilayer suggests several possible mechanisms for virus maturation.

It is possible to think of the formation of viral glycoprotein-containing patches, with decreased lipid fluidity, as a lateral phase separation. The separation of separate lipid phases in a continuous membrane has been observed in membranes of defined lipid composition as a function of temperature (Linden et al., 1973). Phase separations may also occur at a constant temperature as the relative composition of the components changes. In the case of Sindbis virus maturation, once a certain level of viral protein has been inserted into the membrane, spontaneous phase separation may result in differential protein concentration and composition in the separate phases. The ability of the viral glycoproteins to immobilize surrounding lipids and the exclusion of host-cell proteins from budding virus may indicate that host cell proteins partition preferentially into the more fluid, non-viral phase when the viral phase is forming. The partition of membrane proteins into the fluid phase during a temperature-induced phase separation of Escherichia coli membranes has been observed (Kleeman \& McConnell, 1974).

The molecular nature of the very specific yet non-covalent interaction of the internal viral protein with the external viral glycoproteins across the lipid bilayer is unknown. It is not clear whether the proteins interact directly or whether their interaction occurs at a distance and is mediated by lipid. It is possible that the recognition of virally-modified areas of the membrane by the viral ribonucleoprotein core depends on the altered fluidity of the membrane lipids. This recognition could be based on (i) an affinity for areas of the membrane with at least one leaflet of the bilayer containing non-fluid lipid, or (ii) an affinity for areas of the membrane from which normal cellular membrane proteins are absent.

It is also possible that the internal and external viral proteins interact directly within the lipid domain of the membrane. Therefore, it is of interest to know how deeply the viral proteins penetrate into the lipid bilayer. Since the presence of the viral proteins strongly immobilizes the acyl chains of the lipids eight carbons from the polar head group (Fig. 3), it seems reasonable that the proteins penetrate the bilayer to this depth. However, it is impossible to draw a firm conclusion about protein penetration further into the lipid bilayer. Spin labeled whole virus and spin labeled extracted viral lipids are only slightly different when the nitroxide is twelve carbons from the polar head group (Fig. 3) and indistinguishable when the nitroxide is sixteen carbons from the polar head group (Fig. 5). It has been demonstrated, using spin labeled fatty acids, that the membrane proteins of Halobacterium cutirubrum significantly reduce the fluidity of the membrane lipids at the center of the bacterial membrane lipid bilayer (Esser \& Lanyi, 1973), and that the center of the lipid bilayer is rigid in a boundary layer of lipid surrounding cytochrome oxidase in model membranes (Jost et al., 1973). In both of these studies, the ratio of protein to phospholipid $(5: 1, w / w)$, was much greater than in the Sindbis membrane. At low protein to lipid ratios, as in Sindhis $(2: 1, w / w)$, the effect of the proteins on the paramagnetic resonance spectra of labels in the highly fluid center of the bilayer may be below the level of detection even if the proteins penetrate as deeply as the center of the bilayer.

It has been estimated from X-ray diffraction measurements of the Sindbis bilayer dimensions that less than $10 \%$ of the total surface area of the Sindbis membrane is occupied by non-lipid (protein) components (Harrison et al., 1971), yet the results prosented here demonstrate that the viral proteins have a substantial effect on the 


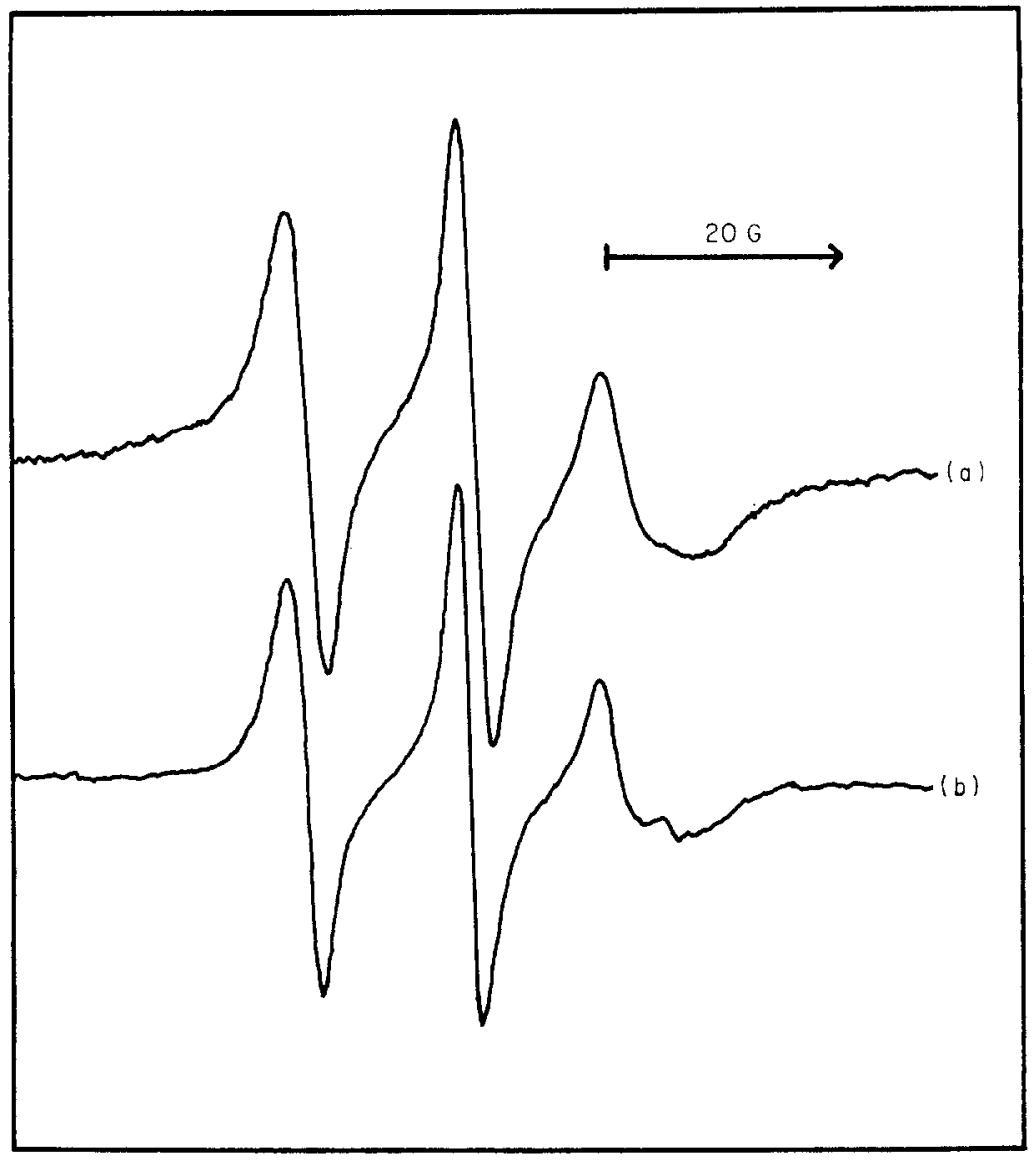

FIG. 5. The paramagnetic resonanoe spectra of spin label III $(1,14)$ in (a) intaot Sindbis virus and (b) an aqueous suspension of viral lipids. Spectra were recorded at $37^{\circ} \mathrm{C}$.

physical properties of the membrane lipids. This result can be compared with the quantitative analysis of the effect of rhodopsin on the fluidity of phospholipids in an artificial, recombined system (Hong \& Hubbell, 1972). With rhodopsin, it was found that a change in order parameter equal to the observed difference between intact Sindbis virus and extracted viral lipids $(0 \cdot 12$ order parameter unit) required the incorporation into lipids of 1.2 mole per cent of rhodopsin. Given this value and assuming (i) that the average area of egg lecithin in the recombinant membrane is approximately $60 \AA^{2}$ and (ii) that the effective radius of rhodopsin in retinal rod membranes is between $15 \AA$ and $30 \AA$ (Poo \& Cone, 1974), one can calculate that the minimum fraction of the surface area occupied by rhodopsin in the above described recombinant is approximately $13 \%$. While there is necessary uncertainty in comparison of the measurements with Sindbis virus and rhodopsin, due to differences in temperature, lipid composition, and possibly orientation of the proteins in the membrane, it seems reasonable that the Sindbis proteins are as intimately associated with membrane lipid as is rhodopsin and may in fact have an even greater effect on the physical properties of surrounding lipid. 
Spin label studies have been performed with a number of other enveloped viruses (Landsberger et al., 1971,1973). These results are different in one important respect from those obtained here. Proteolysis does not affect the fluidity of the membrane of influenza virus, as it does with Sindbis virus. The reason for this difference is not clear although it probably refleots differences in the interaction of the viral glycoproteins with the membrane lipids. In this context, it now appears that proteolysis makes the membrane of vesicular stomatitus virus more fluid (Lenard \& Compans, 1974).

Rigidity of the viral membrane relative to that of the host cell may be a common feature of enveloped animal viruses. This generalization is suggested by three separate observations, using spin labeled fatty acids, on the membrane fluidity of influenza virus, human erythrocytes and mammalian and avian fibroblasts. It has been observed (Landsberger et al., 1971) that the membrane of influenza virus was at least as rigid as that of human erythrocytes. Human erythrocytes, in turn, have been demonstrated to be distinctly more rigid than either mouse $L$ cells (Kaplan et al., 1973) or secondary chick fibroblasts (Gaffney et al., 1974). Thus, while a direct comparison of the fluidity of the influenza virus membrane and the membrane of its host cell has not been made, it seems fair to conclude that influenza virus, like Sindbis virus, has a membrane that is more rigid than the membranes of typical tissue culture fibroblasts.

Two final points should be noted. The effect of incubation at $30^{\circ} \mathrm{C}$ for 24 hours on the inherent fluidity of the membrane of chick cells was minimal (Table 2). It was, in theory, possible that the cell might alter membrane lipids so as to maintain a constant physical state of the membrane, as has been observed with $E$. coli (Sinenski, 1974). This apparently does not occur quickly in chick cells because cells incubated for 24 hours at $30^{\circ} \mathrm{C}$ have the same fluidity as similar cells maintained for this interval at $37^{\circ} \mathrm{C}$, when the measurement is made at $37^{\circ} \mathrm{C}$ (Table 2 ).

Finally, chemical analysis of Sindbis virus grown in chick cells indicates that it contains more cholesterol per mole of membrane lipid than does any of a number of plasma membrane preparations from chick cells. It was observed here that the extracted viral lipids are slightly less fluid than the lipids extracted from cellular membranes. Since cholesterol affects membrane fluidity (Shimshick \& MeConnell, 1973), the chemical data and the spin label data taken together suggest that the virus may acquire a lipid bilayer which is richer in cholesterol than is the cellular membrane in which it matured. This could be due to a tendency of the virus to assemble in regions of the membrane containing greater than the average amount of cholesterol or could be due to cholesterol being asymmetrically distributed in the cellular membrane and the incorporation by the virus of more of one leaflet of the cellular lipid bilayer than the other. The second possibility is attractive because, due to the small radius of the virion, the outer leaflet of the Sindbis lipid bilayer has an area more than $50 \%$ larger than the inner leaflet, and because asymmetric distribution of cholesterol has been postulated for the myelin membrane (Caspar \& Kirschner, $1971)$.

We are indebted to Harden McConnell, Phil Robbins and Boyce Burge for many stimulating discussions and for support. We thank Richard Holm for kindly making an electron paramagnetic resonance spectrometer available to us during many of these studies. This work was supported by the National Institutes of Health grants no. 1-RO1-CA15997. 01 to one of us (B. G.) and no. 5-ROl-CAl4142-11 (to P. Robbins), by grant no. VC-137 
from the American Cancer Society (to B. Burge), by a grant from the Research Corporation (to B. G.) and by grant no. GB33501X1 from the National Science Foundation (to H. McConnell). One of us (B. S.) was a recipient of a postdoctoral fellowship from the Damon Runyon Memorial Fund for Cancer Research.

\section{REFERENCES}

Acheson, N. H. \& Tamm, I. (1967). Virology, 32, 128-143.

Brown, D. T., Waite, M. R. F. \& Pfefferkorn, E. (1972). J. Virol. 10, 524-536.

Caspar, D. L. D. \& Kirschner, D. A. (1971). Nature New Biol. 231, 46-52.

Compans, R. W. (1971). Nature New Biol. 229, 114-116.

Dulbecco, R. \& Vogt, M. (1954). J. Exp. Med. 99, 167-182.

Eagle, H. (1959). Science, 130, 432-437.

Esser, E. F. \& Lanyi, J. K. (1973). Biochemistry, 12, $1933-1938$.

Gaffney, B. J. (1974). Meth. in Enzymol. 34, in the press.

Geffney, B. J., Branton, P. E., Wickus, G. G. \& Hirschberg, C. B. (1974). In Viral Trans. formation and Endogenous Viruses (A. Kaplan, ed.), Academic Press, New York, in the press.

Gahmberg, C. G., Utermann, G. \& Simons, K. (1972). FE ESS Letters, 28, 179-182.

Harrison, S. C., David, A., Jumblatt, J. \& Darnell, J. E. (1971). J. Mol. Biol. 60, 523528.

Hirschberg, C. B. \& Robbins, P. W. (1974). Virology, in the press.

Hong, K. \& Hubbell, W. L. (1972). Proc. Nat. Acad. Sci., U.S.A. 69, 2617-2622.

Hubbell, W. L. \& McConnell, H. M. (1971). J. Amer. Chem. Soc. 93, 314-326.

Jost, P. C., Capaldi, R. A., Vanderkooi, G. \& Griffith, O. H. (1973). J. Supramol. Struc. 1, 269-280.

Kaplan, J., Canonico, P. G. \& Caspary, W. J. (1973). Proc. Nat. Acad. Sci., U.S.A., 70, 66-70.

Kleeman, W. \& MeConnell, H. M. (1974). Biochim. Biophys. Acta, 345, 220-230.

Kornberg, R. D. \& MoConnell, H. M. (1971). Biochemistry, 10, 1111-1120.

Laemmli, U. K. (1970). Nature (London), 227, 680-685.

Landsberger, F. R., Lenurd, J., Paxton, J. \& Compans, R. W. (1971). Proc. Nat. Acad. Sci., U.S.A. 68, 2579-2583.

Landsberger, F. R., Compans, R. W., Choppin, P. W. \& Lenard, J. (1973). Biochemistry, $12,4498-4502$.

Lenard, J. \& Compans, R. W. (1974). Biochim. Biophys. Acta, 344, 51-94.

Linden, C., Wright, K., McConnell, H. M. \& Fox, C. F. (1973). Proc. Nat. Acad. Sci., U.S.A. 70, 2271-2275.

MeNamee, M. G. \& McConnell, H. M. (1973). Biochemistry, 12, 2951-2958.

Perdue, J. F., Kletzien, R. \& Miller, K. (1971). Biochim. Biophys, Acta, 249, 419-434.

Pfefferkorn, E. R. \& Hunter, H. S. (1963). Virology, 20, 446-456.

Poo, M. \& Cone, R. A. (1974). Nature (London), 247, 438-441.

Quigley, J. P., Rifkin, D. P. \& Reich, E. (1971). Virology, 46, 106-116.

Rein, A. \& Rubin, H. (1968). Exp. Cell Res. 49, 466-478.

Robbins, P. W. \& Maopherson, I. A. (1971). Proc. Roy. Soc. (ser. B), 177, 49-58.

Sefton, B. M. \& Burge, B. W. (1973). J. Virol. 12, 1366-1374.

Sefton, B. M. \& Keegstra, K. (1974). J. Virol. 14, 522-530.

Sefton, B. M., Wickus, G. G. \& Burge, B. W. (1973). J. Virol. 11, 730-735.

Shimshick, E. J. \& MeConnell, H. M. (1973). Biochem. Biophys. Res. Commun. 53, 446451.

Sinenski, M. (1974). Proc. Nat. Acad. Sci., U.S.A. 71, 523-525.

Strauss, J., Burge, B. W. \& Darnell, J. E. (1969). Virology, 37, 367-376.

Utermann, G. \& Simons, K. (1974). J. Mol. Biol. 85, 569-587. 